\title{
MODERASI KUALITAS AUDIT DALAM PENGARUH MANAJEMEN LABA TERHADAP KUALITAS LABA KOMPREHENSIF
}

\author{
Kurnia Robik \\ Ahmad Naruli \\ Marhaendra Kusuma* \\ Universitas Islam Kadiri \\ Coresponden Author : marhaenis@uniska-kediri.ac.id
}

\begin{abstract}
Abstrak
Kualitas laba bersih dan laba komprehensif memiliki peranan penting dalam pengambilan keputusan investor untuk berinvestasi. Penelitian ini dilakukan untuk mengetahui pengaruh manajemen laba terhadap kualitas laba perusahaan dengan moderasi kualitas audit pada perusahaan LQ45tahun 2018-2020. Teknik pengambilan sampel dalam penelitian ini menggunakan metode purposive sampling dengan memberikan kriteria tertentu. Sampel yang digunakan adalah laporan keuangan perusahaan BEI LQ45 tahun 2018-2020. Teknik analisis yang digunakan meliputi uji asumsi klasik, analisis regresi linier bergada, analisis regresi moderasi menggunakan software SPSS 21. Hasil analisis menunjukkan manajemen laba baik riil maupun akrual berpengaruh negatif terhadap kualitas laba bersih dan laba komprehensif serta kualitas audit mampu memperlemah pengaruh negatif dari manajemen laba riil dan akrual terhadap kualitas laba bersih dan komprehensif.
\end{abstract}

Kata Kunci: Manajemen Laba, Kualitas Laba Komprehensif, Kualitas Audit

\section{Abstract}

The quality of net income and comprehensive income has an important role in making investor decisions to invest. This research was conducted to find out the effect of earnings management on the quality of company profits by moderating the quality of audits in LQ45 companies in 2018-2020. The sampling technique in this study used purposive sampling methods by providing certain criteria. The sample used is the company's financial statements LQ45 in 2018-2020. Analytical techniques used assumption tests, multiple linear regression analysis, moderate regression analysis with using SPSS 21 software. The results of the analysis showed that both real and accrual earnings management negatively affect the quality of net income and comprehensive income and audit quality was able to weaken the negative influence of real and accrual earnings management on the quality of net and comprehensive income. 


\section{Keywords: Earnings Management, Comprehensive Income Quality, Audit Quality. \\ I. PENDAHULUAN}

Investor saham membeli saham berkinerja baik memiliki kepercayaan bahwa harga saham tersebut akan terus naik dan mengalami peningkatan, sebaliknya saham dengan kinerja buruk akan tetap berada pada kinerja buruk.Ada berbagai macam jenis produk investasi yang bergulir di masyarakat diantaranya reksadana, emas, properti, saham dan deposito. Tiga teknik yang dapat dilakukan untuk memilih portofolio aktif sebelum melakukan pembelian saham, yaitu pemilihan saham, rotasi sektor dan strategi momentum harga (Kusumawardana, 2016). Di Indonesia sendiri, ada 38 indeks saham yang terdaftar pada Bursa Efek Indonesia yang dapat menjadi pilihan bagi calon investor, salah satunya adalah Indeks LQ45. Indeks LQ45 merupakan indeks pasar saham yang mengukur kinerja harga saham dari 45 perusahaan yang memiki tingkat likuiditas yang tinggi serta kapitalisasi pasar dengan didukung fundamental perusahaan yang baik. Pemilihan saham dilakukan dengan menganalisis fundamental perusahaan yang berupa laporan keuangan tahunan. Laporan keuangan tahunan memiliki beberapa komponen utama dan yang sering digunakan untuk mengamati kinerja perusahaan yaitu laporan laba rugi.

PSAK 1 Revisi 2009 setelah konvergensi IFRS di Indonesia menyatakan perusahaan wajib menyajikan laporan posisi keuangan pada akhir periode yang berupa: laporan laba rugi komprehensif selama periode, laporan perubahan ekuitas selama periode, laporan arus kas selama periode, catatan atas laporan keuangan, informasi komparatif untuk mematuhi periode sebelumnya dan laporan posisi keuangan pada awal periode komparatif sebelumnya. Pada PSAK 1 revisi 2013, laporan laba rugi komprehensif berganti judul menjadi laporan laba rugi dan penghasilan komprehensif lain. Laba komprehensif berisi pos-pos pendapatan dan beban (termasuk penyesuaian reklasifikasi) seperti keuntungan ataupun kerugian yang terjadi atas revaluasi aset tetap perusahaan, penjabaran laporan keuangan, keuntungan ataupun kerugian aset keuangan dan lindung nilai arus kas yang tidak diakui dalam laporan laba rugi, melainkan yang langsung mempengaruhi ekuitas.

Motivasi penelitian ini adalah pengembangan penelitian yang dilakukan oleh Rahayu dan Darmawati (2011) dengan judul Pengaruh Kualitas Audit terhadap hubungan Earnings Management dan Return Saham. Pada penelitian tersebut, Rahayu dan Darmawati menjelaskan pentingnya informasi laba dalam laporan keuangan bagi pihak eksternal perusahaan mengakibatkan kecenderungan manajer perusahaan untuk melakukan praktik manajemen laba. Penelitian ini juga merupakan pembaharuan atas penelitian sebelumnya yang dilakukan oleh Riyanti dan Sudarmawanti (2019) dengan judul Pengaruh Manajemen Laba terhadap Earnings Response Coefficient dengan Kualitas Audit sebagai variabel moderasi. Penelitian ini memberikan pembaharuan dimana kualitas laba yang diukur menggunakan Earnings Respons Coefficient atas laba komprehensif dan laba bersih serta manajemen laba yang juga diukur dengan manjemen laba riil dan 
akrual sedangkan pada penelitian Riyanti dan Sudarmawanti (2019) hanya menggunakan ERC yang diukur menggunakan laba akuntansi (laba kotor) sedangkan manajemen laba diukur menggunakan manajemen laba riil.

Sistem akuntansi yang digunakan saat ini dalam penyusunan laporan keuangan merupakan akuntansi berbasis akrual, dimana pendapatan diakui ketika perusahaan menjual barang atau menyerahkan jasa, terlepas dari kapan uang kas akan diterima. Keleluasaan yang diberikan oleh standar akuntansi dalam memilih metode akuntansi yang digunakan dalam perusahaan serta adanya sistem akuntansi akrual mampu menimbulkan sikap tidak etis dalam penyusunan laporan keuangan. Hal ini dilakukan manajemen untuk mempengaruhi tingkat laba yang dihasilkan, salah satunya adalah dengan melakukan tindakan manajemen laba. Manajemen laba merupakan tindakan dalam menurunkan keberagaman laba pada beberapa periode penyusunan laporan keuangan melalui pemindahan keuntungan antara periode yang sebelumnya baik ke periode yang buruk, antara periode laporan keuangan saat ini ke periode laporan keuangan setelahnya dana atau melalui beragam kombinasi lainnya dengan tujuan tertentu (Subramanyam, 2017: 226).

Penelitian yang dilakukan oleh Roychowdhury (2006) menyatakan bahwa manajemen laba dapat dilakukan melalui discretionary accrual atau juga dapat dilakukan dengan manipulasi aktivitas riil (real earnings management). Relevansi penyajian laporan keuangan akan terpengaruh karena adanya praktik manajemen laba sehingga informasi laba dalam laporan keuangan perusahaan akan menjadi bias. Laba yang ditampilkan tidak dapat mencerminkan laba sesungguhnya hal ini dapat menyesatkan para stakehoulder yang mempunyai kepentingan dengan laporan keuangan tersebut. Tingginya respon pasar terhadap laba yang ditampilkan tercermin dari tingkat ERC yang tinggi. Artinya, semakin berkualitas laba yang ditampilkan maka semakin tinggi tingkat ERC.

Auditor yang berkualitas dibutuhkan untuk menilai laba dalam laporan keuangan yang dihasilkan perusahaan serta pemeriksaan atas laporan keuangan yang dihasilkan entitas guna mencegah dan mengurangi potensi kecurangan dalam laporan keuangan dan memastikan kualitas pelaporan keuangan (Boedhi dan Ratnaningsih, 2015). Auditor dengan kualitas yang tinggi diharapkan mampu mendeteksi tindakan manajemen laba yang dilakukan perusahaan klien sehingga pihak investor tidak merasa tercurangi. Dilatarbelakangi dari hal-hal yang telah dipaparkan sebelumnya diatas, maka penulis merasa tertarik untuk membahas lebih lanjut mengenai manajemen laba dengan judul, "Pengaruh kualitas audit terhadap hubungan manajemen laba riil dan akrual dengan kualitas laba bersih dan komprehensif (Studi Kasus pada Perusahaan BEI LQ45 Tahun 2018-2020).

\section{TINJAUAN PUSTAKA}

A. Telaah Teori

Kualitas Laba

Menurut Subramanyam (2017: 123-124) Kualitas laba diartikan sebagai relevansi laba dalam mengukur kinerja suatu perusahaan. Witjaksono dan 
Djaddang (2018: 99) menyatakan kualitas laba dalam hal stabilitas laba dalam memprediksi pendapatan dimasa mendatang. Kualitas laba juga diartikan sebagai persistensi akrual terhadap arus kas, estimasi salah saji dalam proses akrual, tidak adanya manajemen laba dan konservatisme laporan keuangan. Sedangkan indikator baik buruknya laporan keuangan dapat tercermin dari besarnya reaksi pasar terhadap laba yang dihasilkan oleh perusahaan yang diukur dengan Earnings Respons Coeficient (Nursopiatin dan Widyasari, 2020: 147)

\section{Laba Bersih}

Subramanyam (2017: 373) mendefinisikan laba bersih (net income / laba neto) sebagai hasil akhir pengukuran laba yang dihasilkan dari transaksi yang terjadi selama periode tersebut. Namun, laba neto tidak memasukkan keuntungan dan kerugian (pemilik) yang belum direalisasi yang timbul karena perubahan nilai aser dan liabilitas yang dicerminkan dalam laporan posisi keuangan. Menurut Kasmir (2016: 303), "laba bersih merupakan laba yang telah dikurangi biaya yang merupakan beban perusahaan dalam suatu periode tertentu, termasuk pajak".

\section{Laba Komprehensif}

Subramanyam (2017: 373) mendefinisikan laba komprehensif (comprehensive income / penghasilan komprehensif) sebagai sebuah gambaran dari semua perubahan ekuitas, selain yang berasal dari aktivitas pemilik. Yang dalam hal ini merupakan angka laba terakhir yang mecangkup keuntungan dan kerugian yang belum direalisasi oleh entitas. Menurut Dwi Martani, dkk (2015: 110-111): Penghasilan komprehensif lain (Other comprehensive income) merupakan komponen ekuitas yang dipresentasikan dalam laporan penghasilan komprehensif yang mencerminkan total penghasilan dikurang beban (termasuk penyesuaian reklasifikasi) yang tidak diakui dalam laba rugi sebagaimana yang disyaratkan dalam SAK lainnya.

Laporan keuangan adalah media manajemen untuk menyampaikan kinerja keuangan kepada para pemangku kepentingan (Kusuma, 2017b). Semakin baik kinerja keuangan perusahaan, semakin mampu perusahaan memenuhi kewajibannya kepada para pemangku kepentingan terkait pembayaran dividen, bunga, gaji, pajak dan kewajiban lainnya (Kusuma, 2016; Kusuma, 2017a). Laporan keuangan dalam penyajiannya dipengaruhi oleh kebijakan Standar Akuntansi Keuangan (SAK) yang berlaku di negara dimana perusahaan beroperasi. Perubahan kebijakan SAK Indonesia yang terbaru adalah ditambahkannya informasi penghasilan komprehensif lain (OCI) dalam laporan laba rugi (Kusuma, 2021c). Adanya OCI membuat laporan keuangan semakin memiliki nilai relevansi bagi pemangku kepentingan (Kusuma et al., 2021; Kusuma, Assih, et al., 2021; Kusuma, 2020). Adanya OCI juga mempengaruhi rumus mengukur kinerja keuangan menggunakan ROA (Kusuma, 2021b). OCI sendiri kemunculannya disebabkan perubahan makro ekonomi (Kusuma, 2021a) dan dapat digunakan untuk memperkirakan kas masa berikutnya (Kusuma, 
2020b). Walaupun OCI belum terealisasi, namun tidak digunakan sebagai alat manajemen laba (Kusuma, Chandrarin, et al., 2021).

Manajemen Laba

Hosseini et al., (2016:233) memaparkan bahwa manajemen laba yang dilakukan melalui rekayasa baik riil maupun akrual dapat mengurangi tingkat ketepatan laba yang dilaporkan, menurunkan kepercayaan investor dan juga pihak-pihak eksternal perusahaan yang memiliki kepentingan terhadap laporan keuangan serta menimbulkan ketidakseimbangan informasi yang dimiliki oleh pihak manajemen perusahaan dengan para investor sehingga mampu menurunkan tingkat investasi pada perusahaan. Menurut Listyorini (2010:101) manajemen laba merupakan proses yang dilakukan dengan sengaja dalam batasan general accepted accounting principle yang mengarah pada tingkat pelaporan laba yang diinginkan. Manajemen laba adalah sebuah kesalahan atau kelalaian yang disengaja dalam membuat laporan mengenai fakta material atau data akuntansi sehingga mampu menyesatkan ketika semua informasi itu dipakai untuk membuat pertimbangan yang akhirnya akan menyebabkan orang yang membacanya akan mengganti atau mengubah pendapat atau keputusannya.

\section{Kualitas Audit}

Menurut Mathius Tandiontong (2016:80), kualitas audit tercermin dari: Orientasi masukan yang meliputi penugasan personel oleh KAP untuk melaksanakan perjanjian, konsultasi, supervisi, pengangkatan, pengembangan profesi, promosi dan inspeksi. Orientasi proses yang meliputi independensi, kepatuhan pada standar audit, pengendalian audit dan kompetensi auditor. Orientasi keluaran meliputi kinerja auditor, penerimaan dan kelangsungan kerjasama dengan klien dan due professional care. Kualitas audit dapat menggambarkan bagaimana seorang auditor memiliki kemampuan dalam melakukan tugas dan fungsi pengawasan secara mandiri tanpa terpengaruh adanya hubungan dengan perusahaan yang diaudit serta melaksanakan pengawasan audit secara sistematis sesuai dengan peraturan dan ketentuan prosedur auditing yang berlaku.

\section{B. Perumusan Hipotesis}

Manajamen laba merupakan sebuah tindakan rekayasa laba yang dilakukan oleh oknum manajemen perusahaan, salah satunya adalah dengan cara melakukan manipulasi atas aktivitas atau kegiatan operasional perusahaan seperti menurunkan nilai beban-beban beban penjualan, beban administrasi dan umum serta beban penelitian dan pengembangan. Hal ini dilakukan untuk mempengaruhi nilai laba bersih yang dihasilkan, ketika nilai beban berkurang maka laba bersih akan meningkat. Meningkatkanya nilai laba bersih dari nilai yang sebenarnya pada laporan keuangan tahunan dapat mempengaruhi tingkat kepercayaan investor terhadap perusahaan. Semakin tinggi kualitas atas laporan keuangan dalam 
memperoleh kewajaran laba maka semakin tinggi pula tingkat kepercayaan investor terhadap perusahaan dalam menanamkan modalnya.

H1: Diduga manajemen laba riil berpengaruh negatif terhadap kualitas laba bersih

Laporan keuangan merupakan dasar untuk melihat dan menilai kinerja dari suatu perusahaan. Investor dapat menilai keberhasilan kinerja perusahaan salah satunya melalui laporan laba rugi komprehensif perusahaan. Namun, laba yang tinggi tidak bermakna bahwa perusahaan dalam keadaan sehat, hal ini dimungkinkan terjadi karena adanya praktik manajemen laba yang dilakukan oleh oknum tertentu perusahaan. Adanya pengungkapan others comprehensive income pada laporan laba rugi komprehensif dapat meningkatkan kualitas laba perusahaan karena pengungkapan informasi yang lebih transparan mampu menurunkan praktik manajemen laba yang dilakukan perusahaan. Perusahaan yang mengungkapkan informasi keuangan secara transparan pada publikasi laporan keuangan yang diterbitkan di Bursa Efek akan direspon oleh pasar sebagai pertanda dari naik turunnya nilai perusahaan.

H2: Diduga manajemen laba riil berpengaruh negatif terhadap kualitas laba komprehensif

Manajemen laba akrual merupakan tindakan campur tangan manajemen dalam menaik turunkan nilai laba dari laba yang sebenarnya pada laporan keuangan perusahaan dengan tujuan untuk menampilkan kondisi keuangan dan kinerja perusahaan yang baik dimata investor. Hal ini dilakukan karena adanya perbedaan kepentingan antara pemilik perusahaan dengan pengelola perusahaan. Adanya perbedaan kepentingan antara pengelola dan pemilik mendorong oknum manajemen perusahaan untuk mengelola laba perusahaan yaitu dengan mengubah sistem akuntansi yang digunakan untuk mempengaruhi nilai laba bersih perusahaan. Naik turunnya jumlah laba yang dilaporkan perusahaan sangat berpengaruh pada kualitas laba perusahaan. Semakin tinggi kualitas akrual perusahaan dalam hal ini tidak adanya manajemen laba yang dilakukan oknum perusahaan maka akan semakin meningkat kualitas laba perusahaan. Hal ini tercermin dari tingginya respon investor atas laba yang dipublikasikan oleh perusahaan.

H3: Diduga manajemen laba akrual berpengaruh negatif terhadap kualitas laba bersih.

Adanya pengungkapan full disclosure yang digunakan secara menyeluruh terutama setelah adanya peraturan Otoritas Jasa Keuangan no. VIII. G7 tahun 2012 tentang penyajian dan pengungkapan laporan keuangan perusahaan publik yang mana mewajibkan setiap emiten untuk mengungkapkan laba komprehensif dalam laporan keuangan mampu menurunkan tingkat manajemen laba yang dilakukan oleh manajemen perusahaan. Adanya pengakuan pendapatan ataupun aktivitas diluar operasi normal perusahaan memudahkan investor dalam mengevaluasi laba yang dihasilkan oleh perusahaan. Dengan adanya 
pengungkapan other comprehensive income pada laporan keuangan dapat mengurangi intensitas perusahaan dalam melakukan praktek manajemen laba secara akrual.

H4: Diduga manajemen laba akrual berpengaruh negatif terhadap kualitas laba komprehensif

Kualitas audit merupakan kemampuan auditor dalam menemukan salah saji, kecurangan pada laporan keuangan perusahaan, hasil dari auditing tersebut kemudian akan dilaporkan pada pihak manajemen perusahaan. Pada kasus manajemen laba, rekayasa melalui aktivitas riil memberikan dampak buruk yang sangat besar pada arus kas masa depan perusahaan apabila tidak dapat terdeteksi. Auditor yang melakukan pemeriksaan terhadap laporan keuangan perusahaan yang terindikasi adanya rekayasa laba memiliki risiko ligitasi yang lebih besar daripada perusahaan dengan tindak manajemen laba akrual didalamnya karena rekayasa laba melalui aktivitas riil dinilai menimbulkan dampak yang lebih besar kedepanya. Laporan keuangan dengan adanya tindak manajemen laba riil didalamnya dapat menyesatkan para pemangku kepentingan dan juga pemilik perusahaan. Untuk menghindari rasa ketidakpercayaan tersebut maka perusahaan memilih auditor yang berkualitas untuk menjembatani para pemangku kepentingan, salah satunya dengan memilih auditor yang tergolong dalam Big Four.

H5: Diduga kualitas audit memperlemah pengaruh negatif manajemen laba riil terhadap kualitas laba bersih

Kecenderungan perusahaan untuk selalu terlihat berkinerja baik dimata investor menyebabkan manajemen perusahaan tetap melakukan manajemen laba terlepas dari ada atau tidaknya auditor independen yang melakukan audit. Besar kecilnya perusahaan mengundang praktik manajemen laba yang dilakukan oleh perusahaan, semakin besar perusahaan maka semakin besar tingkat praktik manajemen laba (Winarto dan Mulyadi, 2019). Pengungkapan laba komprehensif membantu para investor untuk lebih memahami isi laporan keuangan. Investor lebih mempercayai kualitas laporan keuangan yang telah mendapat rekomendasi auditor yang memiliki kualitas audit yang baik. Penilaian auditor tentang kualitas dari laporan keuangan yang disusun perusahaan akan memotivasi pemangku kepentingan terutama investor dalam peningkatan permintaan terhadap saham perusahaan sehingga volume perdagangan akan meningkat dan tentunya akan meningkatkan nilai perusahaan dimata pemangku kepentingan.

H6: Diduga kualitas audit memperlemah pengaruh negatif manajemen laba riil terhadap kualitas laba koprehensif

Investor akan melakukan berbagai pertimbangan sebelum memutusakan untuk berinvestasi. Salah satunya dengan menilai ada atau tidaknya noise dalam laporan keuangan perusahaan. Tidak adanya noise dalam laporan keuangan mengindikasikan bahwa laporan keuangan yang dibuat oleh perusahaan jauh dari 
adanya tindak manajemen laba sehingga kualitas dari laba yang diperoleh perusahaan akan baik. Investor akan menilai dengan semakin berkualitasnya seorang auditor maka dapat menurunkan noise dalam diskresioneri akrual dalam tindak manajemen laba. Adanya KAP Big Four mampu menjembatani kebutuhan investor dalam transparasi laporan keuangan yang dihasilkan oleh perusahaan.

H7: Diduga kualitas audit memperlemah pengaruh negatif manajemen laba akrual terhadap kualitas laba bersih

Kualitas laba yang tinggi dapat terlihat dari persistensi laba yang dihasilkan yang tercermin dari harapan investor akan besarnya laba dimasa mendatang yang diimplikasikan oleh laba saat ini atau laba tahun berjalan. Tingginya kualitas akrual mempengaruhi respon investor terhadap laba yang dihasilkan oleh perusahaan. Semakin tinggi kualitas laba, indikator tingkat pencapaian keberhasilan kinerja perusahaan juga semakin meningkat. Kondisi tersebut tidak luput dari auditor yang berkualitas yang mampu menemukan salah saji dan mendeteksi adanya pelanggaran pada penyusunan laporan keuangan perusahaan (Novianti, 2012).

H8: Diduga kualitas audit memperlemah pengaruh negatif manajemen laba akrual terhadap kualitas laba komprehensif

\section{METODE PENELITIAN}

Jenis penelitian yang digunakan dalam penelitian ini adalah penelitian deskriptif kuantitatif. Deskriptif kuantitatif adalah jenis penelitian yang bertujuan mendeskripsikan secara sistematis, faktual, dan akurat mengenai fakta dan sifat populasi tertentu, atau mencoba menggambarkan fenomena secara detail (Mury, 2014:62). Populasi yang digunakan dalam penelitian ini adalah perusahaan yang terdaftar di Bursa Efek Indonesia indeks LQ45 periode 2018-2020. Pada penelitian ini menggunakan teknik purposive sampling. Menurut Sugiyono (2012:122), purposive sampling adalah teknik penentuan sampel dengan pertimbangan tertentu. Berikut kriteria yang menjadi pertimbangan peneliti dalam memilih sampel penelitian:

1. Merupakan perusahaan yang terdaftar pada Bursa Efek Indonesia selama 2018-2020.

2. Perusahaan tidak mengalami kerugian selama tahun penelitian 2018-2020.

3. Perusahaan menggunakan mata uang rupiah dalam laporan keuangan.

4. Perusahaan tidak mengalami merger dan akuisisi selama tahun penelitian.

5. Laporan audit tersedia pada situs web BEI dengan opini unqualified dalam bentuk baku dan unqualified dengan bahasa penjelas.

6. Perusahaan tidak delisting dan listing selama periode 2018-2020.

7. Perusahaan non perbankan.

\section{Definisi Operasional Variabel}

1. Manajemen Laba Riil (REM) model Roychowdury (2006) = 


$$
\frac{\mathrm{REM}}{\mathrm{TAs}}=\alpha_{0}+\underline{\alpha_{1}} \frac{1}{\mathrm{TAs}}+\underline{\alpha_{2}} \underline{\mathrm{S}}+\varepsilon
$$

2. Manajemen Laba Akrual (DAC), Modified Jones Model (Dechow et al., 1995) =
a. Menghitung Total Accrual $\left(\mathrm{TAC}_{\mathrm{t}}\right)$
$\mathrm{TAC}_{\mathrm{t}}=\mathrm{NI}_{\mathrm{t}}-\mathrm{CFO}_{\mathrm{t}}$
b. Menghitung nilai accruals dengan estimasi persamaan regresi:
$\mathrm{TAC}_{\mathrm{t}} / \mathrm{A}_{\mathrm{t}-1}=\alpha_{1}\left(1 / \mathrm{A}_{\mathrm{t}-1}\right)+\alpha_{2}\left(\left(\Delta \mathrm{REV}_{\mathrm{t}}-\Delta \mathrm{REC}_{\mathrm{t}}\right) / \mathrm{A}_{\mathrm{t}-1}\right)+\alpha_{3}\left(\mathrm{PPEt} / \mathrm{A}_{\mathrm{t}-1}\right)+\varepsilon$
c. Perhitungan Nondiscretionary Accruals
$\mathrm{NDAt}=\alpha_{1}(1 / \mathrm{At}-1)+\alpha_{2}\left(\left(\Delta \mathrm{REV}_{\mathrm{t}}-\Delta \mathrm{REC}_{\mathrm{t}}\right) / \mathrm{A}_{\mathrm{t}-1}\right)+\alpha_{3}\left(\mathrm{PPE}_{\mathrm{t}} / \mathrm{A}_{\mathrm{t}-1}\right)$
d. Menghitung Discretionary Accruals
$\mathrm{DAC}_{\mathrm{t}}=\mathrm{TAC}_{\mathrm{t}} / \mathrm{A}_{\mathrm{t}-1}-\mathrm{NDA}_{\mathrm{t}}$

Keterangan:

$\mathrm{TAC}_{\mathrm{t}}=$ Total accrual tahun $\mathrm{t}$

$\mathrm{NI}_{\mathrm{t}} \quad=$ Laba bersih tahun $\mathrm{t}$

$\mathrm{CFO}_{\mathrm{t}}=$ Arus kas aktivitas operasi tahun $\mathrm{t}$

$\mathrm{A}_{\mathrm{t}-1}=$ Total Aset tahun $\mathrm{t}-1$

$\Delta \mathrm{REV}_{\mathrm{t}}=$ Pendapatan pada tahun $\mathrm{t}$ dikurangi pendapatan tahun $\mathrm{t}-1$ dibagi total aset tahun $\mathrm{t}-1$

$\Delta \mathrm{REC}_{\mathrm{t}}=$ Net Receivable pada tahun $\mathrm{t}$ dikurangi net receivable pada tahun $\mathrm{t}-1$ dibagi total aset pada tahun $\mathrm{t}-$

$\mathrm{PPE}_{\mathrm{t}}=$ Gross property plant dan perlengkapan (Aktiva tetap) pada tahun $\mathrm{t}$.

\section{Kualitas Laba Bersih $\left(\mathbf{E R C}_{\mathrm{NI}}\right)$ dan Kualitas Laba Komprehensif $\left(\mathbf{E R C}_{\mathbf{C I}}\right)$}

Mengacu pada model penelitian Riyanti dan Sudarmawanti (2019). Pada model ini peneliti menggunakan model sesuaian pasar (market adjusted model). Untuk mencari periode peristiwa peneliti menggunakan tanggal publikasi hasil audit sebagai periode $t 0$ peristiwa dan menggunakan batasan periode $t+7, t-7$. Hal ini dilakukan agar data yang diambil lebih efektif dalam menangkap peristiwa karena jika terlalu pendek, data tidak akan menangkap peristiwa secara utuh namun jika terlalu panjang maka akan menimbulkan confounding events yang mampu menyebabkan hasil menjadi bias (Hartono, 2018:23-26).

a. Menghitung Return Realisasi $\left(\mathrm{R}_{\mathrm{it}}\right)$ diperoleh dari closing price saham $\mathrm{R}_{\mathrm{it}}=\left(\mathrm{P}_{\mathrm{it}}-\mathrm{Pi}_{\mathrm{t}-1}\right) / \mathrm{Pi}_{\mathrm{t}-1}$

b. Menghitung Return Ekspektasi $\left(\mathrm{R}_{\mathrm{mt}}\right)$, diperoleh dari closing price IHSG $\mathrm{R}_{\mathrm{mt}}=\left(\mathrm{IHSG}_{\mathrm{t}}-\mathrm{IHSG}_{\mathrm{t}-1}\right) / \mathrm{IHSG}_{\mathrm{t}-1}$

c. Menghitung Abnormal Return (AR) $\mathrm{AR}_{\mathrm{it}}=\mathrm{Ri}_{\mathrm{t}}-\mathrm{Rm}_{\mathrm{t}}$

d. Menghitung Cummulative Abnormal Return (CAR) dengan menjumlahkan return tidak normal perusahaan i setiap tahunnya.

e. Menghitung Unexpected Earnings $\left(\mathrm{UE}_{\mathrm{NI}}\right)$ dan $\left(\mathrm{UE}_{\mathrm{ci}}\right)$ dengan mencari nilai laba bersih dan laba komprehensif setiap perusahaan pada tahun $\mathrm{t}$ dan $\mathrm{t}-1$

- $\mathrm{UE}_{\mathrm{NI}}=\left(\mathrm{Ei}_{\mathrm{t}}-\mathrm{Ei}_{\mathrm{t}-1}\right) / \mathrm{Ei}_{\mathrm{t}-1}$

$\mathrm{UE}_{\mathrm{CI}}=\left(\mathrm{Ei}_{\mathrm{t}}-\mathrm{Ei}_{\mathrm{t}-1}\right) / \mathrm{Ei}_{\mathrm{t}-1}$ 
f. Melakukan Regresi CAR sebagai Y dan $\mathrm{UE}_{\mathrm{NI}} / \mathrm{UE}_{\mathrm{CI}}$ sebagai X untuk memperoleh koefisien regresi dari $\alpha_{0}$ dan $\alpha_{1}$

g. Menghitung $\mathrm{ERC}_{\mathrm{NI}}$ dan $\mathrm{ERC}_{\mathrm{CI}}$

- $\quad \mathrm{ERC}_{\mathrm{NI}}=\alpha_{0}+\alpha_{1} \mathrm{UE}_{\mathrm{Ni}}+\varepsilon$

- $\quad \mathrm{ERC}_{\mathrm{CI}}=\alpha_{0}+\alpha_{1} \mathrm{UE}_{\mathrm{ci}}+\varepsilon$

Keterangan:

Rit $\quad=$ Return realisasi tahun $\mathrm{t}$

Rmt = Return Ekspektasi tahun $\mathrm{t}$

$\mathrm{P}_{\mathrm{it}} \quad=$ Harga saham perusahaan i pada waktu $\mathrm{t}$

$\mathrm{Pi}_{\mathrm{t}-1} \quad=$ Harga saham perusahaan i pada waktu $\mathrm{t}-1$

$\mathrm{IHSG}_{\mathrm{t}}=$ Harga saham perusahaan i pada waktu t-1

$\mathrm{IHSG}_{\mathrm{t}-1}=$ Indeks harga saham gabungan pada waktu $\mathrm{t}-1$

$\mathrm{AR}_{\text {it }} \quad=$ Abnormal Return untuk perusahaan i pada hari ke-t.

$\mathrm{UE}_{\mathrm{NI}}=$ Unexpected Earnings laba bersih perusahaan i pada periode $\mathrm{t}$

$\mathrm{Ei}_{\mathrm{t}} \quad=$ Laba bersih perusahaan i pada periode

$\mathrm{Ei}_{\mathrm{t}-1}=$ Laba bersih perusahaan pada periode sebelumnya

$\mathrm{UE}_{\mathrm{CI}}=$ Unexpected Earnings laba komprehensif perusahaan i pada periode $\mathrm{t}$

$\mathrm{Ei}_{\mathrm{t}} \quad=$ Laba komprehensif perusahaan i pada periode

$\mathrm{Ei}_{\mathrm{t}-1} \quad$ = Laba komprehensif perusahaan pada periode sebelumnya

$\mathrm{ERC}_{\mathrm{NI}}=$ Earnings response coefficient laba bersih

$\mathrm{ERC}_{\mathrm{CI}}=$ Earnings response coefficient laba komprehensif

\section{Kualitas Audit (AQ)}

Kualitas audit perusahaan dengan menggunakan ukuran auditor brand name yaitu dengan menilai kualitas audit berdasarkan reputasi nama baik auditor independen yang juga diukur dengan variabel dummy (1 untuk Big Four dan 0 untuk Non Big Four) (Rahayu dan Darmawati, 2011).

\section{HASIL PENELITIAN DAN PEMBAHASAN}

\section{Statistik Deskriptif}

Variabel ERC NI, ERC CI, REM, DAC, AQ memiliki nilai N sebesar 48 data. Nilai minimum ERC NI menunjukkan -0,05 dan maximum sebesar 0,04 serta $s t$. deviation menunjukkan 0,01813. Artinya batas penyimpangan variabel kualitas laba bersih (ERC NI) dalam penelitian sebesar 0,01813. Nilai minimum ERC CI menunjukkan -0,05 dan maximum sebesar 0,07 serta std. deviation menunjukkan 0,01993. Artinya batas penyimpangan variabel kualitas laba komprehensif (ERC CI) dalam penelitian sebesar 0,01993.

Tabel 1. Uji Statistik Deskriptif

\begin{tabular}{|l|r|r|r|}
\hline Variabel & \multicolumn{1}{c|}{ Min } & Max & Std. Deviation \\
\hline ERC NI &,- 05 &, 04 &, 01813 \\
\hline ERC CI &,- 05 &, 07 &, 01993 \\
\hline REM &, 03 &, 36 &, 09163 \\
\hline DAC &,- 15 &, 13 &, 05532 \\
\hline AQ & 0 & 1 &, 41041 \\
\hline
\end{tabular}

Sumber: Data diolah, 2021. 
Nilai minimum REM menunjukkan 0,03 dan maximum sebesar 0,36 serta std. deviation menunjukkan 0,09163. Artinya batas penyimpangan variabel manajemen laba riil (REM) dalam penelitian sebesar 0,09163. Nilai minimum DAC menunjukkan $-0,15$ dan maximum sebesar 0,13 serta std. deviation menunjukkan 0,05532. Artinya batas penyimpangan variabel manajemen laba akrual (DAC) dalam penelitian sebesar 0,05532. Nilai minimum AQ menunjukkan 0,00 dan maximum sebesar 0,01 serta std. deviation menunjukkan 0,41041. Artinya batas penyimpangan variabel kualitas audit (AQ) dalam penelitian sebesar 0,41041 .

\section{Analisis Regresi Moderasi}

Tabel 2. Analisis Regresi Moderasi

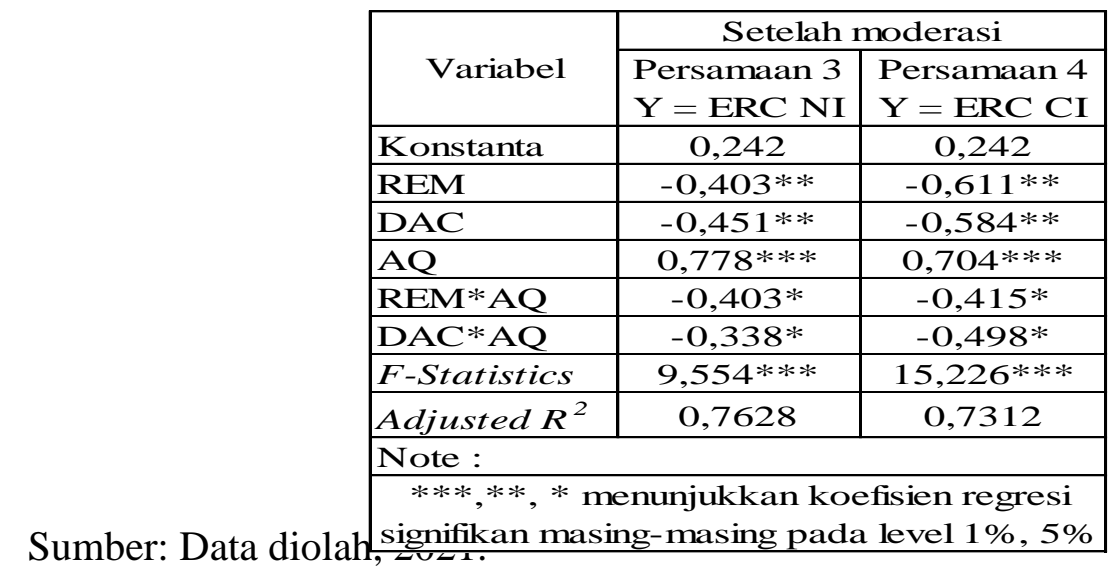

Persamaan 3:

$$
\begin{aligned}
\mathrm{ERC}_{\mathrm{NI}} & =0,242-0,403(\mathrm{REM})-0,451(\mathrm{DAC})+0,778(\mathrm{AQ})-0,403\left(\mathrm{REM}{ }^{*} \mathrm{AQ}\right)- \\
& 0,338(\mathrm{DAC} * \mathrm{AQ})+\mathrm{e}
\end{aligned}
$$

Konstanta sebesar 0,242, artinya jika variabel independen dianggap konstan, maka kualitas laba bersih (ERCNI) yang hasilkan sebesar 0,242. Koefisien regresi manajemen laba riil (REM) sebagai variabel X1 yaitu sebesar -0,403 menunjukkan bahwa jika manajemen laba riil mengalami peningkatan sebesar 1 maka akan menurunkan kualitas laba bersih sebesar -0,403 dan juga sebaliknya.

Dari tabel 2 diketahui hasil uji simultan $\mathrm{F}$ untuk persamaan 1 dan 2 didapatkan hasil $\mathrm{F}_{\text {hitung }}$ 11,451 dan 9,554 dengan signifikansi 0,000 lebih kecil dari 0,05. Sehingga dapat disimpulkan bahwa secara bersama-sama terdapat pengaruh manajemen laba riil, manajemen laba akrual terhadap kualitas laba bersih dan laba komprehensif. Pada persamaan 3 dan 4 didapati hasil $F_{\text {hitung }}$ 9,554 dan 15,226 dengan signifikansi $0,000<0,05$ maka dapat diartikan bahwa secara bersamasama terdapat pengaruh manajemen laba riil, manajemen laba akrual dan kualitas audit terhadap kualitas laba bersih dan laba komprehensif. 


\section{Uji Koefisien Determinasi}

Dari tabel 2 pada persaman 1 dapat diketahui jika nilai Adjusted $R$ Square yang diperoleh adalah 0,6118 . Hal ini menunjukkan bahwa variabel manajemen laba riil (REM) dan manajemen laba akrual (DAC) memberikan pengaruh 61,18\% terhadap kualitas laba bersih $\left(\mathrm{ERC}_{\mathrm{NI}}\right)$. Sedangkan 38,82\% dipengaruhi oleh variabel lainnya yang tidak digunakan dalam penelitian ini. Sedangkan pada persamaan 2 dengan $\mathrm{Y}_{1.2}$ adalah kualitas laba komprehensif nilai Adjusted $R$ Square yang diperoleh adalah 0,6287. Hal ini menunjukkan bahwa variabel manajemen laba riil (REM) dan manajemen laba akrual (DAC) memberikan pengaruh $62,87 \%$ terhadap kualitas laba komprehensif $\left(\mathrm{ERC}_{\mathrm{CI}}\right)$. Sedangkan $37,13 \%$ dipengaruhi oleh variabel lainnya yang tidak digunakan dalam penelitian ini. Dari tabel 8 diketahui jika nilai Adjusted $R$ Square pada persamaan 3 dengan $\mathrm{Y}_{1.1}$ adalah kualitas laba bersih (ERC NI) yang diperoleh adalah 0,7628. Hal ini menunjukkan bahwa variabel kualitas audit (AQ) dapat memoderasi pengaruh antara manajemen laba riil (REM) dan manajemen laba akrual (DAC) terhadap kualitas laba bersih $\left(\mathrm{ERC}_{\mathrm{NI}}\right)$ sebesar 76,28\%, sedangkan 23,72\% dipengaruhi oleh variabel lainnya yang tidak digunakan dalam penelitian ini. Pada persamaan-4 dengan $\mathrm{Y}_{1.2}$ adalah kualitas laba komprehensif $\left(\mathrm{ERC}_{\mathrm{CI}}\right)$ yang diperoleh adalah 0,7312. Artinya, variabel kualitas audit (AQ) dapat memoderasi pengaruh antara manajemen laba riil (REM) dan manajemen laba akrual (DAC) terhadap kualitas laba komprehensif (ERC CI) sebesar 73,12\% sedangkan 26,88\% dipengaruhi oleh variabel lainnya yang tidak digunakan dalam penelitian ini.

\section{Pengaruh Manajemen Laba Riil terhadap Kualitas Laba Bersih}

Berdasarkan hasil $t_{\text {hitung }}$ manajemen laba riil (X1) sebesar -0,604

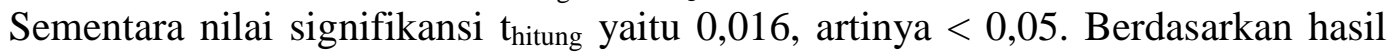
tersebut maka $\mathrm{H} 0$ ditolak dan $\mathrm{H} 1$ diterima yang artinya manajemen laba riil berpengaruh negatif terhadap kualitas laba bersih. Hasil dari penelitian ini konsisten dengan hasil penelitian yang dilakukan oleh Riyanti dan Sudarmawanti (2019) yang menyatakan bahwa manajemen laba riil berpengaruh terhadap Earnings Response Coefficient perusahaan. Manajemen laba riil merupakan rekayasa laba yang dilakukan oleh oknum perusahaan yang dilakukan dengan cara menaik atau menurunkan biaya operasional perusahaan. Besar kecilnya tingkat manajemen laba yang dilakukan oleh oknum perusahaan memberikan pengaruh negatif terhadap kualitas laba perusahaan yang diukur dengan menggunakan koefisien respon laba. Semakin meningkat tindak manajemen laba maka kualitas dari laba yang dihasilkan akan semakin menurun. Investor yang memahami tindak manajemen laba dalam laporan keuangan akan menghindari resiko untuk berinvestasi pada perusahaan tersebut.

\section{Pengaruh Manajemen Laba Riil terhadap Kualitas Laba Komprehensif}

Hasil penelitian menyatakan nilai $t_{\text {hitung }}$ manajemen laba riil (X1) sebesar 0,703 sementara nilai signifikansi $t_{\text {hitung }}$ yaitu 0,000 , artinya $<0,05$. Berdasarkan hasil tersebut maka $\mathrm{H} 0$ ditolak dan $\mathrm{H} 2$ diterima yang artinya manajemen laba riil 
berpengaruh negatif terhadap kualitas laba komprehensif. Hasil penelitian ini sejalan dengan penelitian yang dilakukan oleh Bima dan Yuyetta (2017) serta Wang Lin Men Rong (2012) bahwasannya adanya pengungkapkan laba komprehensif dalam laporan keuangan perusahaan dapat menurunkan tingkat manajemen laba yang dilakukan oknum perusahaan. Pengungkapan laba rugi komprehensif akan mampu meningkatkan kualitas dari laba komprehensif itu sendiri. Semakin transparan informasi dari laporan keuangan menunjukkan kualitas kinerja perusahaan yang semakin baik yang dibuktikan dengan kualitas laba yang baik. Disisi lain dengan rendahnya transparansi informasi akan berdampak pada pemangku kepentingan yang memiliki kebutuhan terhadap laporan keuangan perusahaan. Semakin berkualitas laba komprehensif pada laporan keuangan maka akan semakin menurunkan tingkat manajemen laba perusahaan, sebaliknya apabila manajemen laba meningkat maka kualitas laba komprehensif perusahaan akan menurun.

\section{Pengaruh Manajemen Laba Akrual terhadap Kualitas Laba Bersih}

Hasil penelitian menyatakan nilai thitung manajemen laba akrual (X2) sebesar $-0,621$ sementara nilai signifikansi thitung yaitu 0,016 , artinya $<0,05$. Berdasarkan hasil tersebut maka $\mathrm{H} 0$ ditolak dan $\mathrm{H} 3$ diterima yang artinya manajemen laba akrual berpengaruh negatif terhadap kualitas laba bersih. Bagi seorang investor, naik dan turunnya nilai laba merupakan sebuah cerminan kinerja dari suatu perusahaan. Laporan keuangan dengan indikasi manajemen laba didalamnya dapat menyesatkan para pemangku kepentingan sehingga praktik manajemen laba dapat mengakibatkan kualitas laba yang rendah karena informasi laba yang dipublikasikan tidak dapat mencerminkan kondisi nyata keuangan perusahaan atau kinerja ekonomi perusahaan.

Hasil penelitian ini sejalan dengan hasil penelitian yang dilakukan oleh Prasetyo, dkk (2017) dimana manajemen laba berpengaruh negatif terhadap kinerja perusahaan. Semakin tinggi rekayasa laba yang dilakukan oleh oknum perusahaan, menurunkan kualitas laba perusahaan yang mencerminkan buruknya kinerja perusahaan dalam mengelola ekonomi perusahaan. Hasil penelitian ini juga sependapat dengan hasil penelitian yang dilakukan dari Novianti (2012) menyatakan bahwa kualitas akrual berpengaruh posisitf terhadap kualitas laba perusahaan. Semakin tinggi kualitas akrual perusahaan dimana hal ini terlihat dari tidak adanya manajemen laba yang dilakukan perusahaan akan mampu meningkatkan kualitas laba perusahaan. Namun apabila kualitas akrual itu rendah terlihat dari tingginya manajemen laba yang dilakukan oknum perusahaan, maka dapat menurunkan kualitas dari laba perusahaan.

\section{Pengaruh Manajamen Laba Akrual terhadap Kualitas Laba Komprehensif}

Hasil penelitian menyatakan nilai thitung manajemen laba akrual (X2) sebesar -0,646 sementara nilai signifikansi thitung yaitu 0,002, artinya $<0,05$. Berdasarkan hasil tersebut maka $\mathrm{H} 0$ ditolak dan $\mathrm{H} 4$ diterima yang artinya manajemen laba akrual berpengaruh negatif terhadap kualitas laba komprehensif. 
Hasil penelitian ini sejalan dengan hasil peneltian yang dilakukan oleh Kin Lo (2007) menyatakan bahwa manajemen laba akrual berpengaruh negatif terhadap kualitas laba, investor sebagai pemegang peranan penting dalam kebutuhan laporan keuangan meyakini bahwa kualitas dari laporan laba yang dihasilkan perusahaan dapat memberikan pengaruh kedepannya terhadap imbal balik return yang akan didapatkan. Semakin baik kualitas dari laba komprehensif perusahaan maka akan semakin meningkat respon pasar terhadap informasi laba, sebaliknya jika kualitas laba dari laporan keuangan buruk yang ditandai dengan tingginya manajemen laba yang dilakukan oknum perusahaan maka respon pasar akan rendah atau tidak memberikan respon (Sugiarto dan Deviesa, 2017).

\section{Peran moderasi Kualitas audit dalam Pengaruh Manajemen Laba Riil terhadap Kualitas Laba Bersih}

Hasil penelitian menyatakan nilai thitung manajemen laba riil (X1) setelah moderasi sebesar $-0,403$ sementara nilai signifikansi thitung yaitu 0,011 , artinya < 0,05 . Nilai thitung lebih rendah dari nilai thitung sebelum moderasi yakni $-0,604$. Berdasarkan hasil tersebut maka $\mathrm{H} 0$ ditolak dan $\mathrm{H} 5$ diterima yang artinya kualitas audit mampu memperlemah pengaruh manajemen laba riil terhadap kualitas laba bersih. Hal ini dapat dibuktikan dari nilai koesfisien negatif yang melemah setelah adanya moderasi dari kualitas audit dan signifikan. Audit yang berkualitas dinilai mampu untuk membatasi pergerakan oknum manajer perusahaan dalam melakukan tindak manajemen laba yang akan berdampak pada kualitas laba perusahaan. Kualitas laba yang rendah dapat menurunkan nilai dari perusahaan dan akan berimbas pada arus kas dimasa yang akan datang karena karena laporan keuangan yang dibuat tidak sesuai dengan laba yang sesungguhnya.

Hasil penelitian ini sejalan dengan penelitian yang dilakukan oleh Darmawan (2020) dimana kualitas audit mampu memperlemah pengaruh negatif pada manajemen laba riil terhadap nilai perusahaan. Nilai perusahaan yang baik dipandang mampu menampilkan kondisi dari kualitas laba yang tinggi dari sebuah perusahaan, sehingga investor akan lebih tertarik untuk menanamkan modalnya pada perusahaan tersebut (Abbas et al, 2017). Hasil penelitian ini membantah penelitian yang dilakukan oleh Riyanti dan Sudarmawanti (2019) dimana kualitas audit hanya melakukan pemeriksaan terhadap laporan keuangan untuk meningkatkan kredibiltas laporan keuangan.

\section{Peran Moderasi Kualitas audit dalam Pengaruh Manajemen Laba Riil terhadap Kualitas Laba Komprehensif}

Hasil penelitian menyatakan nilai $t_{\text {hitung }}$ manajemen laba riil (X1) setelah moderasi sebesar $-0,611$ sementara nilai signifikansi $t_{\text {hitung }}$ yaitu 0,021 , artinya $<$ 0,05 . Nilai thitung lebih rendah dari nilai $t_{\text {hitung }}$ sebelum moderasi yakni $-0,703$. Berdasarkan hasil tersebut maka $\mathrm{H} 0$ ditolak dan $\mathrm{H} 6$ diterima yang artinya kualitas audit mampu memperlemah pengaruh manajemen laba riil terhadap kualitas laba bersih. Hal ini dapat dibuktikan dari nilai koesfisien negatif yang melemah setelah adanya moderasi dari kualitas audit dan signifikan. 
Hasil penelitian ini menunjukkan bahwa kualitas audit mampu membatasi tindakan rekayasa laba perusahaan yang dapat mempengaruhi kualitas laba perusahaan. Semakin meningkatnya laba komprehensif menunjukkan besarnya peningkatan laba ditahan dan deviden yang akan dibagikan perusahaan kepada pemilik, hal ini memupuk kepercayaan kepada investor untuk terus meningkatkan investasinya sehingga dapat menaikkan harga saham perusahaan. Hasil penelitian ini sesuai dengan penelitian yang dilakukan oleh Darmawan (2020) dimana kualitas audit mampu memperlemah tindak manajemen laba terhadap nilai perusahaan. Meningkatnya nilai perusahaan diiringi dengan kualitas laba yang semakin meningkat karena auditor tidak hanya bertugas sebagai pengawas dan pemeriksa laporan keuangan namun juga dapat membatasi ruang gerak oknum perusahaan dalam manipulasi secara nyata.

\section{Peran Moderasi Kualitas Audit dalam Pengaruh Manajemen Laba Akrual terhadap Kualitas Laba Bersih}

Hasil penelitian menyatakan nilai $t_{\text {hitung }}$ manajemen laba akrual setelah moderasi sebesar $-0,338$ sementara nilai signifikansi $t_{\text {hitung }}$ yaitu 0,061 , artinya $>$ 0,05 . Nilai thitung lebih rendah dari nilai $t_{\text {hitung }}$ sebelum moderasi yakni $-0,621$. Berdasarkan hasil tersebut maka $\mathrm{H} 0$ ditolak dan $\mathrm{H} 7$ diterima yang artinya kualitas audit mampu memperlemah pengaruh manajemen laba akrual terhadap kualitas laba bersih. Hal ini dapat dibuktikan dari nilai koesfisien negatif yang melemah setelah adanya moderasi dari kualitas audit walaupun tidak signifikan.

Hasil penelitian ini sesuai dengan penelitian yang dilakukan oleh Listyorini (2010) yang menyatakan bahwa kualitas audit berpengaruh terhadap hubungan income smoothing dengan ERC. Income smoothing merupakan salah satu tindakan manajemen laba yang dilakukan dengan meratakan laba salah satunya dengan memindahkan pendapatan yang dianggap bernilai tinggi ke tahun dengan pendapatan yang bernilai rendah. Audit yang berkualitas tercermin dari KAP yang memiliki reputasi dan kredibilitas yang baik. Auditor yang berkualitas mampu menurunkan noise dalam diskresioneri akrual dalam tindak manajemen laba yang dilakukan oleh perusahaan. Auditor yang berkualitas juga mampu menghubungkan kepentingan investor atas perolehan informasi yang transparan mengenai laba yang sesungguhnya diperoleh perusahaan. Investor lebih mempercayai laporan keuangan dengan opini audit dari KAP yang berkualitas (Nugraha, 2016).

\section{Peran Moderasi Kualitas audit dalam Pengaruh Manajemen Laba Akrual terhadap Kualitas Laba Komprehensif}

Hasil penelitian menyatakan nilai $t_{\text {hitung }}$ manajemen laba akrual setelah moderasi sebesar $-0,584$ sementara nilai signifikansi $t_{\text {hitung }}$ yaitu 0,022 , artinya $<$ 0,05 . Nilai thitung lebih rendah dari nilai $t_{\text {hitung }}$ sebelum moderasi yakni $-0,646$. Berdasarkan hasil tersebut maka H0 ditolak dan H8 diterima yang artinya kualitas audit mampu memperlemah pengaruh manajemen laba akrual terhadap kualitas 
laba komprehensif. Hal ini dapat dibuktikan dari nilai koesfisien negatif yang melemah setelah adanya moderasi dari kualitas audit dan signifikan.

Pengungkapan laba komprehensif dapat menjelaskan risiko yang mungkin akan dihadapi oleh investor terkait nilai wajar atas aset dan juga liabilitas keuangan karena laporan laba rugi dan komprehensif telah mengungkapkan segala aktivitas baik operasional maupun non operasional perusahaan. Relevansi nilai dari informasi laba dalam laporan keuangan memiliki arti kemampuan informasi laba dalam menjelaskan nilai perusahaan. Hasil penelitian ini selaras dengan penelitian yang dilakukan oleh Darmawan (2020) dimana auditor yang berkualitas mampu memperlemah manajemen laba akrual yang dilakukan oleh perusahaan terhadap nilai perusahaan. Nilai perusahaan tercermin dari tingginya kualitas laba yang disajikan pada laporan keuangan sehingga sangat mempengaruhi tingkat kepercayaan investor. Pasar akan sangat merespon kualitas akrual atas laba yang dipublikasikan (Novianti, 2012). Selain itu, hasil penelitian ini juga mendukung hasil penelitian dari Rahayu dan Darmawati (2011) bahwa kualitas auditor yang diukur menggunakan auditor brand name yang tergolong dalam KAP Big four mampu membatasi praktek manajemen laba yang dilakukan oknum perusahaan hingga mencapai batas wajar serta menghindari adanya peningkatan return saham atas reaksi investor yang merespon informasi keuangan yang dipublikasikan perusahaan.

\section{KESIMPULAN DAN SARAN}

Manajemen laba baik secara riil maupun akrual mampu mengurangi kualitas laba baik laba bersih maupun komprehensif. Semakin tinggi manajemen laba yang dilakukan oleh oknum disebuah perusahaan akan semakin menurunkan kualitas dari laba perusahaan. Tindakan manajemen laba tersebut dapat menurunkan respon investor terhadap informasi laba perusahaan. Kualitas audit mampu memperlemah pengaruh manajemen laba baik riil dan akrual terhadap kualitas laba bersih dan komprehensif. Semakin berkualitas KAP yang melakukan pengawasan terhadap laporan keuangan perusahaan semakin mampu mendeteksi tindak manajemen laba. Kualitas dari KAP itu sendiri dapat terlihat dari semakin baragamnya pengalaman yang dimiliki serta berintegritasnya seorang KAP. Opini audit yang diberikan atas pengawasan yang dilakukan pada sebuah laporan keuangan perusahaan menjadi sandaran pengguna dalam memaknai informasi yang tersaji dalam laporan keuangan, termasuk dalam hal ini informasi laba. Pengguna juga memaknai laporan keuangan yang berkualitas dari laporan yang diaudit oleh KAP yang memiliki reputasi baik dan berkualitas.

Saran bagi Manajemen Perusahaan agar lebih mengoptimalkan fungsi dari internal auditor sebagai garda pertama dalam mencegah tindak manajemen laba yang mungkin dapat dilakukan perusahaan. Investor sebagai pihak yang berkepentingan untuk pengambilan keputusan berinvestasi agar lebih berhati-hati sebelum menanamkan modal yaitu dengan lebih mendalami pemahaman terkait fundamental laporan keuangan perusahaan dan bijak dalam mengelola portofolio 
saham serta tidak hanya mengikuti trend yang ada. DSAK IAI diharapkan mampu untuk mengkaji ulang peraturan standar akuntansi keuangan yang berlaku agar dapat lebih disempurkan kembali untuk menutup celah bagi oknum yang memiliki kepentingan pribadi dalam rekayasa laporan keuangan. OJK diharapkan ikut berkontribusi dalam pembuatan sanksi terhadap perusahaan yang dengan sengaja melakukan rekayasa laporan keuangan sehingga mengakibatkan kerugian bagi para pemangku kepentingan.

Penelitan selanjutnya dapat menggunakan jenis penelitian kualitatif untuk membuktikan ukuran audit dari sisi Brand Name Big Four dan Non Big Four dan juga menggunakan ukuran kualitas audit dari sisi yang lainnya, memperluas populasi penelitian dengan jumlah sampel dan tahun penelitian yang lebih panjang dan tidak hanya terfokus pada perusahaan yang tergolong dalam perusahaan terdaftar LQ45 sehingga memperoleh hasil penelitian secara umum yang semakin baik, melibatkan Size (ukuran perusahaan) sebagai salah satu variabel yang diharapkan dapat mempengaruhi variabel kualitas laba bersih maupun kualitas laba komprehensif.

\section{DAFTAR PUSTAKA}

Abbas, Z., M. F. Rizwan, dan P. M. A. Khan. (2017). Abnormal Accruals and Firm Value, Panel Data Analisis of Banking Industry of Pakistan. The Journal of Developing Areas, 51 (3), Hal: 281-297.

Ardiati, A.Y. (2005). Pengaruh Manajemen Laba terhadap Return Saham perusahaan yang diaudit oleh KAP Big 5 dan KAP Non Big 5. Jurnal Riset Akuntansi Indonesia, Vol. 8, No. 3, Hal: 235-249.

Barlian, E. (2016). Metodologi Penelitian Kualitatif dan Kuantitatif. Padang: Sukabina Press.

Bima, P.G dan Yuyetta, E.N.A. (2017). Dampak pengungkapan pendapatan komprehensif lain terhadap manajemen laba pada perusahaan manufaktur di Indonesia. Diponegoro Journal of Accounting, Vol. 6, Hal 1-15.

Hosseini et al. (2016). A Study in the Relationship between Earnings Management Incentives and Earnings Response Coefficient. Procedia Economics and 146 Finance, Vol. 36, Hal: 232-243.

Institut Akuntan Publik Indonesia. (2021). Direktori 2021 Kantor Akuntan Publik dan Akuntan Publik.

Indrarini, S. (2019). Nilai Perusahaan Melalui Kualitas Laba. Surabaya: Scopindo Media Pustaka.

Istiádah, U. (2015). Faktor-Faktor yang mempengaruhi Nilai Perusahaan pada Perusahaan Manufaktur. Jurnal Nominal, Vol. IV, No 2, Hal: 57-72.

Kasmir. (2016). Analisis Laporan Keuangan (Edisi 1). Jakarta: Rajawali Pers.

Kusuma, M. (2016). Studi Tentang Beban Pokok Produksi, Pengaruhnya Terhadap Kemandirian Pendanaan Perusahaan Rokok Go Public Di Indonesia. Jurnal Akuntansi Dan Ekonomi JAE, 1(1), 9-25. 
Kusuma, M. (2017a). INTERNALISASI NILAI PANCASILA DALAM MATA KULIAH AKUNTANSI BIAYA (Suatu Studi Pengukuran Efektivitas. Jurnal Akuntansi Dan Ekonomi JAE, 2(2).

Kusuma, M. (2017b). Konstribusi informasi akuntansi biaya dalam meningkatkan nilai perusahaan dan tanggung jawab kepada stakeholder pada perusahaan manufaktur semen di Indonesia. Ekuilibrium, 12(2), 102-118. http://journal.umpo.ac.id/index.php/ekuilibrium/article/view/673/555

Kusuma, M. (2020a). Relevance Value of Comprehensive Income and Operating Cash Flows with Income Attribution and Other Comprehensive Income as A Moderated Variables: Evidence from Indonesia. The $2 \mathrm{Nd}$ Doctoral Colloquium on Business and Economics Program Doktor Ilmu Ekonomi Universitas Sebelas Maret Surakarta.

Kusuma, M. (2021a). Bukti Empiris Pengaruh Fundamental Makro Ekonomi Terhadap Penghasilan Komprehensif Lain dan Persistensi Laba Komprehensif Di Indonesia. Konferensi Regional Akuntansi Ke-VIII Ikatan Akuntan Indonesia Wilayah Jawa Timur.

Kusuma, M. (2021b). Measurement of Return on Asset (ROA) based on Comprehensive Income and its Ability to Predict Investment Returns: an Empirical Evidence on Go Public Companies in Indonesia before and during the Covid-19 Pandemic. Ekuilibrium : Jurnal Ilmiah Bidang Ilmu Ekonomi, 16(1), 94. https://doi.org/10.24269/ekuilibrium.v16i1.3238

Kusuma, M. (2021c). Modification of Profitability Measures with Comprehensive Income and Reclassification of Other Comprehensive Income as A Mediation of Effects Asset Utilization on Firm Value. Jurnal Keuangan Dan Perbankan, 25(4).

Kusuma, M. (2020b). Penghasilan komprehensif lain dan prediksi arus kas masa depan: Bukti dari Indonesia. Seminar Nasional SENIMA Ke 5 Universitas Negeri Surabaya, Senima 5, 815-832. http://bit.ly/ProsidingSenima5

Kusuma, M., Assih, P., \& Zuhroh, D. (2021). Pengukuran Kinerja Keuangan: Return on Equity ( ROE ) Dengan Atribusi Ekuitas. Jurnal Ilmiah Manajemen Dan Bisnis, 22(2), 223-244. https://doi.org/10.30596/jimb.v22i2.7935

Kusuma, M., Chandrarin, G., Sukanti, D., Lisetyani, E., \& Kadiri, U. I. (2021). Paper ID : 31 RECLASSIFICATION OF OTHERS COMPREHENSIVE INCOME, EARNINGS MANAGEMENT AND EARNINGS QUALITY : The 16th Asia-Pacific Management Accounting Association 2021 Annual Conference (APMAA 2021) Universitas Trisakti Jakarta Dan Universitas Udayana Bali APMAA 2021, 1-22.

Kusuma, M., Zuhroh, D., Assih, P., \& Chandrarin, G. (2021). The Effect of Net Income and Other Comprehensive Income on Future's Comprehensive Income With Attribution of Comprehensive Income as Moderating Variable. International Journal of Financial Research, 12(3), 205-219.

Kusumawardana, V. (2016). Komparasi Strategi Investasi Aktif dan Pasif untuk Optimalkan Return Saham yang Terdaftar di Bursa Efek Indonesia. Jurnal: Ekonomika-Bisnis, Vol. 7, No.1, Hal: 41-54. 
Kurniawan, M. (2017). Pendapatan Komprehensif lain Perusahaan Sektor Aneka Industri di Indonesia. Jurnal: Riset Akuntansi dan Perpajakan, Vo.4 No.2, Hal: 259-274.

Lo, K. (2007). Earnings Management and Earnings Quality. Jurnal Of Accounting Economics, 45, pp,350-357.

Listyorini, I. (2010). Pengaruh Income Smoothing terhadap Earnings Response Coefficient: Kualitas Auditor sebagai Pemoderasi. Jurnal KOMPAK, Vol. 17, No. 2, Hal: 99-114.

Luhgiatno. (2010). Analisis Pengaruh Kualitas Audit terhadap Manajemen Laba (Studi Pada Perusahaan yang melakukan IPO di Indonesia). Jurnal Akuntansi Riset, Vol. 2 No.1, Hal 319-334.

Martani, Dwi. dkk. (2015). Akuntansi Keuangan Menengah Berbasis PSAK (Buku 2). Jakarta: Salemba Empat.

Mulchandani, K., Mulchandani, K., Wasan, P. (2020). Dividends and earnings quality: Evidence from India. IIMB Management Review, (32), Hal: 166176.

Novianti, R. (2012). Kajian Kualitas Laba pada Perusahaan Manufaktur Yang Terdaftar di BEI. Accounting Analysis Journal, Vol. 1, No.2, Hal:1-6.

Nugraha, E. (2016). Faktor yang mempengaruhi Manajemen Laba dan Dampaknya terhadap Koefisien Respon Laba. Jurnal SIKAP, Vol. 1, No. 1, Hal: 9- 21.

Nursopiatin, Y dan Widyasari. (2020). Analisis faktor-faktor yang mempengaruhi Earnings Response Coefficient. Jurnal: Multiparadigma Akuntansi Tarumanegara, Vol. 2, No. 1, Hal: 146-155.

Paramita, RWD. Dan Hidayanti, E. (2013). Pengaruh Earnings Response Coeffisient terhadap harga saham. Jurnal WIGA, Vol.3, No.1. Hal: 12- 20.

Prasetyo. dkk. (2017). Pengaruh Manajemen Laba terhadap Kinerja Perusahaan dengan Good Corporate Governance sebagai variabel Moderasi (Studi Kasus pada Perusahaan Manufaktur yang terdaftar di BEI Tahun 2011-2014. Jurnal: Ekonomi Manajemen dan Akuntansi, Vol: 24, No. 43, Hal: 44-48. (27 Oktober 2021).

Rahayu, I dan Darmawati, D. (2011). Pengaruh Kualitas Audit terhadap Hubungan Earnings dengan Return Saham. Jurnal Media Riset Akuntansi, Auditing dan Informasi, Vol: 11, No.2, Hal: 1-28.

Riyanti, B. dan Sudarmawanti, E. (2019). Pengaruh Manajemen Laba terhadap Earnings Response Coefisient dengan Kualitas Audit sebagai Variabel Moderasi. Journal: ECODUNAMIKA, Vol. 2, No. 2.

Rejeki, S.T. dan Warastuti, Y. (2012). Pengaruh Perubahan Laba Bersih, Perubahan Laba Komprehensif dan Perubahan Peringkat Obligasi terhadap Return saham. Jurnal: Akuntansi Bisnis, Vol. X1, No. 21, Hal: 1-16.

Roychowdury, S. (2006). Earnings management through real activities manipulation. Jurnal of Accounting and Economics, 42, Hal: 335-370.

Rusmin. (2010). Auditor Quality and Earnings Management: Singaporean Evidence. Managerial Auditing Journal, Vol. 25, No. 7, Hal: 618-638. 
Santoso, G. (2015). Determinan Koefisien Respon Laba. Jurnal PARSIMONIA, Vol.2, No.2, Hal: 69-85.

Subramanyam, K.R. (2017). Analisis Laporan Keuangan Buku 1 (Edisi 11). Jakarta: Salemba Empat.

Sugiarto, S.V dan Deviesa, D. (2017). Pengaruh Earnings Management terhadap Stock Return dengan Earnings Quality sebagai Variabel Intervening. Jurnal Business Accounting Review, Vol.5, No.1, Hal: 193-204.

Sulistyanto, S.H. (2018). Manajemen Laba: Teori dan Model Empiris (Cetakan 2). Jakarta: PT. Grasindo.

Tandiontong, M. (2016). Kualitas Audit dan Pengukurannya. Bandung: Alfabeta.

Utami, W. (2005). Pengaruh Manajemen Laba terhadap Biaya Modal Ekuitas (Studi pada Perusahaan Publik Sektor Manufaktur). Jurnal: SNA, Vol. 8, Hal: 100- 116. Tersedia: http://doi.org/10.33312/ijar.155. (10 Oktober 2021).

Wang Lin dan Men Rong. (2012). Impact of other comprehensive income disclosure on earnings management. Nankai Business Review International, Emerald Group Publishing, Vol. 3, No. 1, Hal: 93-101.

Winarto, H. dan Mulyadi, JMV. (2019). Pengaruh Komite Audit, Ukuran Perusahaan, Leverage dan Penyajian Other Comprehensive Income terhadap Manajemen Laba Perusahaan Properti Indonesia. Jurnal: Manajemen Bisnis Krisnadwipayana, Vol.7, No.3.

Witjaksono, R. B. dan Djaddang, S. (2018). Valuasi kesadaran lingkungan, corporate social responsibility terhadap kualitas laba dengan moderasi komite audit. Jurnal Ekonomi dan Bisnis, Vol. 21, No. 1, 